\title{
Potential Effect of Increased SRS River Water Withdrawal on the Savannah River Shortnose Sturgeon Population
}

by

L. D. Wike

Westinghouse Savannah River Company

Savannah River Site

Aiken, South Carolina 29808

This paper was prepared in connection with work done under the above contract number with the U.S. Department of Energy. By acceptance of this paper, the publisher and/or recipient acknowledges the U.S. Government's right to retain a nonexclusive, royalty-free license in and to any copyright covering this paper, along with the right to reproduce and to authorize others to reproduce all or part of the copyrighted paper. 
Derivative Classifier

\section{Potential Effect of Increased SRS River Water Withdrawal on the Savannah River Shortnose Sturgeon Population (U)}

Westinghouse Savannah River Company

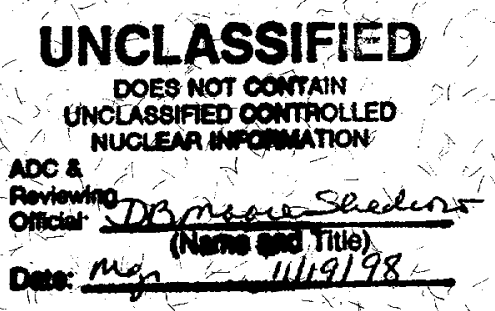
Savannah River Site

Aiken, SC 29808

Prepared for the U.S. Department of Energy under contract no. DE-AC09-96SR18500 


\section{DISCLAIMER}

This report was prepared as an account of work sponsored by an agency of the United States Government. Neither the United States Government nor any agency thereof, nor any of their employees, makes any warranty, express or implied, or assumes any legal liability or responsibility for the accuracy, completeness, or usefulness of any information, apparatus, product, or process disclosed, or represents that its use would not infringe privately owned rights. Reference herein to any specific commercial product, process, or service by trade name, trademark, manufacturer, or otherwise does not necessarily constitute or imply its endorsement, recommendation, or favoring by the United States Government or any agency thereof. The views and opinions of authors expressed herein do not necessarily state or reflect those of the United States Government or any agency thereof.

This report has been reproduced directly from the best available copy.

Available to DOE and DOE contractors from the Office of Scientific and Technical Information, P.O. Box 62, Oak Ridge, TN 37831; prices available from (615) 576-8401.

Available to the public from the National Technical Information Service, U.S. Department of Commerce, 5285 Port Royal Road, Springfield, VA 22161. 


\section{DISCLAIMER}

Portions of this document may be illegible in electronic image products. Images are produced from the best available original document. 
WSRC-TR-98-00424

Rev 0

November 12, 1998

\section{Potential Effect of Increased SRS River Water Withdrawal on the Savannah River Shortnose Sturgeon Population (U)}

Lynn D. Wike

Savannah River Technology Center

Westinghouse Savannah River Company

Prepared for the U.S. Department of Energy under contract no. DE-AC09-96SR18500 
Potential Effect of Increased SRS River Water Withdrawal on the Savannah River Shortnose Sturgeon Population.

The potential impact of SRS operations on shortnose sturgeon (Acipenser brevirostrum) in the Savannah River was evaluated in 1983 in relation to the restart of the L-Reactor at Savannah River Site (SRS) (DOE, 1984). Muska and Matthews (1983) concluded that withdrawal of 380,000 gallons per minute (gpm) from the Savannah River at the SRS intakes would have no affect on the shortnose sturgeon population inhabiting that river system. The Protected Species Management Branch of the U. S. Department of Commerce concurred with the conclusions of this Biological Assessment (Oravetz, 1983). The current assessment examines the potential impact of withdrawing a total of $11,000 \mathrm{gpm}$ from the river with $5,000 \mathrm{gpm}$ attributed to base operations and an additional 6,000 gpm to support the Accelerator Production of Tritium (APT).

The potential effect of increased river water withdrawal on the Savannah River population of the shortnose sturgeon is determined by two factors. These include the volume of water withdrawn by the SRS Riverwater System and the vulnerability of the species in question.

Reviews of the life history of the shortnose sturgeon can be found in several SRS documents (Wike et al., 1994; Muska and Mathews, 1983; Mackey, 1987) as well as the open literature (Dadswell 1979a, 1979b; Dadswell et al., 1982). Specific aspects of the life history that affect impingement include the preferred spawning habitat, nature of the fertilized eggs, and behavior of the larvae. Although several studies have indicated that there is acceptable spawning habitat upstream of the SRS, there have been no areas designated (under the Endangered Species Act of 1973) as critical habitat above the Site (Mackey, 1987; Collins and Smith, 1993). The existence of upstream spawning would indicate there is an adequate zone of passage for adult fish moving past the SRS intake canals (Mackey, 1987). Once eggs have been spawned and fertilized they become negatively buoyant and adhesive. These demersal eggs tend to sink and become attached to the substrate. There are no historic records of shortnose sturgeon eggs being collected near the SRS. Behavior of larval shortnose sturgeon is not well known because during that stage they are cryptic in their habits and may even dwell in the substrate. Larval shortnose sturgeon were collected in the vicinity of SRS during ichthyoplankton surveys conducted between 1982 and 1985 (Paller et al., 1986). During those studies, 13 larval shortnose sturgeon were collected, four of which were taken in or near the intake canals (Mackey, 1987; Paller et al., 1986).

Currently SRS withdraws $5,000 \mathrm{gpm}$ from the Savannah River to meet existing commitments to maintain water levels in L-Lake and flows to Steel Creek (DOE, 1997). The preferred cooling water option for the APT would add $6,000 \mathrm{gpm}$ for a maximum total of $11,000 \mathrm{gpm}$. These values are substantially smaller than the approximately $380,000 \mathrm{gpm}$ withdrawn during the simultaneous operation of $\mathrm{K}-, \mathrm{L}-$, and $\mathrm{P}$ - Reactors in the past (DOE, 1990). The expected demand including APT will be approximately $3 \%$ of the previous withdrawal rates. Extrapolation would lead one to conclude that the proposed rates should result in only $3 \%$ of impingement and entrainment losses experienced during prior operating conditions. Studies conducted during the 1983-1985 
time frame (Paller et al., 1986) estimated that eggs and larvae entrained by SRS operations represented 9.5 and $9.1 \%$ respectively of the total numbers in the river at that location. If these percentages are directly related to intake volume, then a prediction of entrainment under the proposed APT withdrawal volume would be approximately one half of one percent of ichthyoplankton in the river near the intake structure.

During studies conducted from 1990 to 1992, gill nets captured 189 shortnose sturgeon in the lower Savannah River and 51 in the upper river (Collins et al., 1996). There was a $16 \%$ mortality associated with these captures, amounting to approximately 38 adult fish. Those fish were lost in a single year, considering that a single adult female shortnose sturgeon can shed many thousands of eggs for each spawning, those fish represent a far greater potential impact to the population than potential entrainment of one half of one percent of sturgeon ichthyoplankton. In addition, between 1984 and 1992 over 97,000 hatchery spawned shortnose sturgeon were released into the Savannah River, many of which were later recaptured. Over $35 \%$ of captured juvenile shortnose sturgeon from 1990 - 1993 were identifiable as stocked fish (Smith and Collins, 1996). This would indicate a certain level of recruitment into the local populations, especially in the upper reaches of the release areas (Smith and Collins, 1996). Most recent estimations of the size of the Savannah River population of the shortnose sturgeon are between 300 and 3000 (Kennedy et al., 1992), which could be interpreted as a hopeful sign for the status of the species within the local drainage.

The initial biological assessment concluded that the then existing and proposed operations at SRS would not jeopardize the continued existence of the shortnose sturgeon in the Savannah River (Muska and Matthews, 1983). In light of the fact that current and proposed withdrawals of water are a small fraction of those considered in the biological assessment, there is no reason to disagree with the original assessment of the effects of SRS operations on the shortnose sturgeon. 


\section{Literature Cited}

Collins, M. R., S. G. Rogers, T. I. J. Smith. 1996. 'Bycatch of Sturgeons along the Southern Atlantic Coast of the USA. North American Journal of Fisheries Management 16:24-29.

Collins, M. R., T.I. J. Smith. 1993. Characteristics of the Adult Segment of the Savannah River Population of Shortnose Sturgeon. Proc. Annu. Southeast Assoc. Fish and Wildl. Agencies 47:485-491.

Dadswell, M. J. 1979a. Biology and Population Characteristics of the Shortnose Sturgeon Acipenser brevirostrum LeSueur 1818 (Osteichthyes: Acipenseridae) in the Saint John Estuary, New Brunswick, Canada. Can. J. Zool. 57:2186-2210.

Dadswell, M. J. 1979b. Biology and Population Characteristics of the Shortnose Sturgeon Acipenser brevirostrum LeSueur 1818 (Osteichthyes: Acipenseridae) in the Saint John Estuary, New Brunswick, Canada. In: Baseline Survey and Living Resource Potential of the Saint John Estuary Vol. 3. Huntsman Marine Laboratory, St. Andrews.

Dadswell, M. J., B. D. Taubert, T. S. Squires, D. Marchette, J. Buckley. 1984. Synopsis of the Biological Data on Shortnose Sturgeon Acipenser brevirostrum LeSueur 1818. Natl. Oceanic and Atmos. Admin (NOAA) Tech Rep. NMFS-14, FAO Fish Synopsis No. 140.

DOE (U. S. Department of Energy). 1984. Final Environmental Impact Statement LReactor Operation Savannah River Plant. DOE/EIS-0108. Savannah River Operations Office, Aiken, SC.

DOE (U.S. Department of Energy). 1990. Final Environmental Impact Statement Continued Operation of K-, L-, and P-Reactors Savannah River Site Aiken, South Carolina. DOE/EIS-0147. Savannah River Operations Office, Aiken, SC.

DOE (U. S. Department of Energy). 1997. Final Environmental Impact Statement Shutdown of the River Water System at the Savannah River Site.' DOE/EIS-0268. Savannah River Operations Office, Aiken, SC.

Kennedy, E. T., M. R. Collins, T. I. J. Smith. 1992. Population Characterisitcs of Shortnose Sturgeon in the Savannah River. U.S. Fish and Wildlife Acipenser/Polyodon Workshop. Atlanta, GA.

Mackey, H. E. 1987. Comprehensive Cooling Water Study, Final Report, Volume 6, Federally Endangered Species. DP-1739-6. E. I. DuPont de Nemours \& Co. Aiken, SC.

Muska, C. F., B. A. Matthews. 1983. Biological Assessment for the Shortnose Sturgeon, Acipenser brevirostrum LeSueur 1818 The Savannah River Plant. DPST-83-754. E. I. DuPont de Nemours \& Co. Aiken, SC.

Oravetz, C. A. 1983. Letter dated November 1, 1983 to M. J. Spires, Assistant Manager, Health, Safety, and Environment, U. S. Department of Energy, Savannah River Plant, from C. A. Oravetz, Chief, Protected Species Branch, U. S. Department of Commerce, National Oceanic and Atmospheric Administration, National Marine Fisheries Service (F/SERV 23:AM:CF). St. Petersburg, FL. 